\title{
INTEGRITAS BUDAYA KERJA BIDANG BIMAS HINDU DENGAN PARISADA DALAM PEMBINAAN UMAT HINDU DI PROVINSI NUSA TENGGARA BARAT
}

\author{
Oleh. I Ketut Nuasa \\ Dosen pada STAHN Gde Pudja Mataram
}

\begin{abstract}
ABSTRAK
Sebuah integritas Bidang Bimas Hindu dengan Parisada sebagai budaya kerja berwujud baik, akan berdampak terhadap umat Hindu yang merupakan masyarakat binaannya. Untuk memperbaiki budaya kerja membutuhkan waktu untuk merubahnya, maka dari itu perlu adanya pembenahanpembenahan yang dimulai dari sikap dan tingkah laku sebagai pemimpin pada lembaga umat Hindu. Demikian juga masing-masing pimpinan lembaga umat, baik Bidang Bimas Hindu maupun Parisada telah memilki tugas dan fungsi masing-masing. Tugas dan fungsi Bidang Bimas Hindu dengan Parisada dalam melakukan pembinaan, yaitu 1) melaksanakan pelayanan dan bimbingan masyarakat Hindu, 2) melaksanakan fungsi penjabaran dan pelaksanaan kebijakan teknis di bidang bimbingan masyarakat Hindu, 3) akan terjaganya keutuhan masyarakat Hindu dengan mengakomodasikan kearifan budaya lokal, dan 4) terwujudnya masyarakat Hindu yang berkualitas dan memiliki srada dan bhakti yang mampu diaktualisasikan secara modern.
\end{abstract}

Kata kunci; Integritas budaya kerja Bimas Hindu, Parisada dalam pembinaan umat Hindu.

\section{ABSTRACT}

A Hindu integrity Guidance Division with Parisada as a tangible good work culture, will have an impact on Hindus who constitute the community auxiliaries. To improve the work culture takes time to change, then there is need for reform-reform that starts from the attitude and behavior as the leader of the institution Hindus. Likewise, each of the leaders of institutions of the people, both Hindu and Parisada Sector Guidance has have the duties and functions of each.

Duties and functions of Sector Guidance Hindu Parisada in fostering, namely 1) carry out the services and guidance of Hindu society, 2) carry out the functions of the elaboration and implementation of technical policy in the guidance of the Hindu community, 3) will be maintained the integrity of the Hindu community to accommodate local cultural wisdom, and 4) the realization of the Hindu community that qualified and capable srada and bhakti modern actualized.

Keywords: Work integrity Guidance Hindu culture, Parisada in coaching people.

\section{PENDAHULUAN}

Dalam proses pencapai kemajuan, meningkatnya sumber daya manusia maupun dalam bidang-bidang pembangunan dan pendidikan, semua itu tidak lepas dari kesiapan Bimas Hindu dengan Parisada sebagai pemimpin pada suatu lembaga umat Hindu dalam menyediakan pelayanan yang mampu bersaing dalam era globalisasi seperti sekarang ini. Kualitas pemimpin yang baik adalah sebagai dasar utama dalam menyiapkan sumber daya manusia yang mampu bersaing dalam dunia global, tentunya diperlukan suatu kedaulatan budaya kerja antara Bidang Bimas Hindu dengan Parisada sebagai pemimpin umat Hindu secara profesional 
dalam melaksanakan tugas memberikan pembinaan terhadap umat Hindu di daerah Nusa Tenggara Barat.

Pengelolaan budaya kerja Bidang Bimas Hindu dengan Parisada dalam melakukan pembinaan umat Hindu di Provinsi Nusa Tenggara Barat guna terciptanya disiplin kerja, dalam proses pencapaian kemajuan, meningkatnya sumber daya manusia maka diperlukan komitmen dan upaya dari seorang pemimpin dalam hal ini adalah Kepala Bidang Bimas Hindu. Upaya itu dapat dilakukan melalui proses pembinaan-pembinaan berupa ceramah dalam meningkatkan pemahaman agama, dan bantuan berupa material untuk menunjang pembangunan terhadap kepentingan umat Hindu yang terarah guna mancapai kehidupan yang harmonis

Budaya kerja yang ditetapkan oleh lembaga umat Hindu antara Kepala Bidang Bimas Hindu dengan Parisada dimaksud untuk meningkatkan etos kerja sebagai pelayanan umat. Hal ini penting dilakukan dalam rangka meningkatkan citra positif sebagai lembaga agama bagi umat beragama di bawah Kementerian Agama di mata masyarakat. Budaya kerja yang telah disepakati merpakan nilai-nilai yang tepat dan sesuai dalam upaya meningkatkan kinerja aparatur negara yaitu Bidang Bimas Hindu untuk memberikan pelayanan prima kepada masyarakat.

Sesuai dengan Peraturan Mentri Agama No 13 tahun 2012 tentang Organisasi dan Tata Kerja InstansiV ertikal Kementerian Agama, Tugas dan Fungsi Bimas Hindu adalah Melaksanakan pelayanan, bimbingan, pembinaan, pendidikan dan pengelolaan sistem informasi di bidang bimbingan masyarakat Hindu berdasarkan kebijakan teknis yang ditetapkan oleh Kepala Kantor Wilayah Kementerian Agama. Suatu keistimewaan daerah yang ada di luar Bali, hanya daerah Provinsi Nusa Tengara Barat, satu-satunya daerah yang memiliki Kepala Bidang Bimas Hindu yang bertugas memberikan pelayanan, bimbingan dan pembinaan kepada umat
Hindu, sedangkan daerah-daerah yang lain untuk melayani umat Hindu di daerah adalah Pembimas. Bidang Bimas Hindu akan berkembang apabila budaya organisasi sebagai sistem terdiri atas komponenkomponen (subsistem) yang saling berkaitan atau bergantungan (interdependence) satu sama lain dalam proses kerja Bidang Bimas Hindu dengan Parisada. Subsistem yang saling tergantung adalah tujuan dan nilainilai (goals and values subsystem), teknikal (technical system), manajemen (managerial system), dan sub-substruktur (structural system). Dalam proses interaksi antara suatu subsistem dan subsistem lainnya tidak ada jaminan akan selalu terjadi kesesuaian antara Bidang Bimas Hindu dengan Parisada dan masyarakat atau kecocokan antar individu dengan pelaksananya. Adanya budaya kerja dalam organisasi yang berkembang dalam suatu instansi akan memberikan pengaruh kepada perilaku anggota Bidang Bimas Hindu tersebut.

Pasca reformasi 1998, Kementerian Agama memang telah banyak menunjukkan berbagai perbaikan. Hal ini dapat dilihat dari keseriusannya dalam meningkatkan kinerja aparatur negara sebagai pelayanan umat, perbaikan sistem, perwujudan pemerintahan yang baik dan bersih, serta last but not least, upaya menumbuhkembangkan budaya kerja, untuk menjaga agar arus perubahan yang baik pada Kementerian Agama ini berjalan pada jalur yang benar, maka budaya kerja yang telah disepakati dan ditetapkan perlu terus diimplementasikan secara konsisten.

Konsistensi perilaku Bidang Bimas Hindu Kementerian Agama Provinsi Nusa Tenggara Barat merupakan bagian dari budaya organisasi dalam menghadapi lingkungan. Namun, konsistensi itu dapat mendorong atau sebaliknya menghambat organisasi dalam menanggapi perubahan lingkungan. Dengan kata lain, walaupun konsistensi itu dapat meningkatkan fungsi organisasi secara kelembagaannya, tidak semua konsistensi 
bermanfaat bagi organisasi (Evers \& Lakomski, 1992). Alasannya kinerja pada Bidang Bimas Hindu dengan kinerja Parisada serta bagaimana sense of belonging terhadap birokrasi tidak dapat dipahami dengan baik, kecuali dengan memahami budayanya.

Sementara kenyataan di lapangan saat ini menunjukkan bahwa pembinaan Bidang Bimas Hindu Kementerian Agama Provinsi Nusa Tenggara Barat dan Parisada terhadap umat Hindu dalam memberikan pembinaan belum berjalan maksimal. Hal tersebut menyebabkan beberapa hal. pertama, proses pembinaan di masyarakat masih sifatnya menunggu dari kepentingan masyarakat artinya Bidang Bimas Hindu dengan Parisada sebagai perpanjangan tangannya dalam melakukan pembinaan kepada umat Hindu tidak terjadwal rutin setiap bulan. Kedua, budaya kerja Bidang Bimas Hindu dengan Parisada sebagai perpanjangan tangan di daerah terhadap pembinaan belum mampu menyentuh sampai kekantong-kantong umat Hindu yang ada di daerha terpencil. Harapan masyarakat yang paling dominan terhadap pembinaan, Bidang Bimas Hindu dengan Parisada merupakan lembaga yang tidak dapat terpisahkan, dan sebagai pasilitator terhadap umat Hindu untuk memberikan pembinaan, sehingga umat Hindu mendapat pencerahan agama. Melalui pembinaan semacam ini nilainilai agama akan bisa memberikan dampak positif terhadap kehidupan beragama.

\section{PEMBAHASAN}

\section{A. Budaya Kerja Bimas Hindu dengan Parisada dalam Melakukan Pembinaan Umat Hindu di Provinsi Nusa Tengara Barat}

Budaya kerja yang terbentuk secara positif oleh kedua lembaga baik dari Bidang Bimas Hindu maupun Parisada, akan bermanfaat karena setiap umat Hindu yang ada di daerahdaerah dalam suatu organisasi membutuhkan ruang lingkup yang positif dalam membangun masyarakat demi kemajuan umat Hindu di
Nusa Tenggara Barat. Budaya kerja Bidang Bimas Hindu dengan Parisada berwujud baik akan berdampak kepada umat Hindu yang merupakan masyarakat binaannya. Untuk memperbaiki budaya kerja membutuhkan waktu untuk merubahnya, maka dari itu perlu adanya pembenahan-pembenahan yang dimulai dari sikap dan tingkah laku sebagai pemimpin pada lembaga umat Hindu. Demikian juga masing-masing pimpinan lembaga umat, baik Bidang Bimas Hindu maupun Parisada telah memilki tugas dan fungsi masing-masing.

Tugas dan fungsi Bidang Bimas Hindu dalam melakukan pembinaan, yaitu 1) melaksanakan pelayanan dan bimbingan di bidang masyarakat Hindu, 2) melaksanakan fungsi penjabaran dan pelaksanaan kebijakan teknis di bidang bimbingan masyarakat Hindu, 3) meliputi lembaga dan sarana agama penyuluh dan tenaga teknis keagamaan, pendidikan agama Hindu, supervisi pendidikan, dan pelayanan Pura; dan 4) Penyiapan bahan pelayanan dan bimbingan di bidang bimbingan masyarakat Hindu.

Tugas dan fungsi Parisada dalam mengayomi umat Hindu di Nusa Tenggara Barat dengan harapan, 1) akan terjaganya keutuhan masyarakat Hindu dengan mengakomodasikan kearifan budaya lokal; 2) terwujudnya masyarakat Hindu yang berkualitas dan memiliki srada dan bhakti yang mampu diaktualisasikan secara modern; 3) terwujudnya masyarakat Hindu yang proaktif dalam menjalankan hak dan kewajibannya dalam kehidupan beragama, bermasyarakat, berbangsa dan bernegara; 4) terwujudnya masyarakat Hindu yang cerdasdan berkarakter; dan terwujudnya masyarakat Hindu yang harmonis dan sejahtra lahir batin.

Terbentuknya budaya kerja diantara kedua pimpinan lembaga umat Hindu yaitu antara Bidang Bimas Hindu dengan Parisada dimulai dari tingkat kesadaran kedua pemimpin lembaga, karena besarnya hubungan antara 
kedua pemimpin tersebut dengan masyarakat Hindu yang ada di Provinsi Nusa Tenggara Barat sangat menentukan cara-cara tersendiri apa yang dilakukan dalam perangkat satuan kerja dalam melakukan pembinaan umat Hindu, sehingga setiap nilai budaya kerja akan mampu menumbuhkan hal-hal sebagai barikut: Pertama perlunya disiplin, dengan disiplin perilaku senantiasa berpijak pada peraturan dan norma yang berlaku dalam pembinaan umat sebagai kelompok dalam organisasi. Disiplin meliputi ketaatan terhadap peraturan perundang-undangan, prosedur, waktu kerja, berinterakasi dengan masyarakat dan sebagainya. Kedua, adanya keterbukaan yaitu kesiapan untuk memberi dan menerima informasi yang benar dari masyarakat selaku binaannya untuk kepentingan umat Hindu yang ada di Nusa Tenggara Barat. Ketiga, saling menghargai, perilaku yang menunjukkan penghargaan terhadap masyarakat Hindu, merupakan tugas dan tanggung jawab Bimas Hindu dan Parisada sebagai pengayom umat. Keempat, kerjasama yaitu kesediaan untuk memberi dan menerima kontribusi dari dan atau kepada masyarakat Hindu dalam mencapai sasaran kerja Bidang Bimas Hindu dengan Parisada dalam melakukan pembinaan.

Budaya kerja yang profesional yang diimbangi oleh moral yang tinggi memberikan dampak terhadap tingkat kemajuan umat Hindu. Adanya kerja sama kelompok dalam melakukan pembinaan berimplikasi terhadap kemajuan masyarakat Hindu Nusa Tenggara Barat. Adanya warna pembinaan antara Bidang Bimas Hindu dengan parisada yang diimbangi dengan stategi pembinaan menyebabkan telah diperoleh hasil yang maksimal sebagaimana diharapkan.

Pada prinsipnya fungsi budaya kerja Bidang Bimas Hindu dengan Parisada dalam melakukan pembinaan umat Hindu di Nusa Tenggara Barat bertujuan untuk membangun keyakinan sumber daya manusia atau menanamkan nilai-nilai tertentu yang melandasi atau mempengaruhi sikap dan perilaku umat Hindu yang konsisten serta komitmen, membiasakan suatu cara kerja di lingkungan masing-masing, maka dengan adanya suatu keyakinan dan komitmen kuat merefleksikan nilai-nilai tertentu, misalkan membiasakan kerja berkualitas sesuai dengan aturan-aturan.

Melaksanakan budaya kerja Bidang Bimas Hindu dengan Parisada mempunyai arti yang sangat mendalam, karena kedua pimpinan lembaga umat akan merubah sikap dan perilaku sumber daya manusia umat Hindu untuk mencapai kesadaran dalam keberagaman beragama dan produktivitas kerja yang lebih tinggi dalam menghadapi MEA (Masryarakat Ekonomi Asian) sebagai tantangan masa depan, sehingga menjadi umat Hindu yang unggul dan berdaya saing di dunia global. Disamping itu masih banyak lagi manfaat budaya kerja yang muncul, seperti kepuasan kerja meningkat, pergaulan yang lebih akrab, disiplin meningkat, dan ingin memberikan pelayanan yang terbaik bagi umat Hindu.

\section{Faktor-Faktor Yang Mempengaruhi Budaya Kerja Bimas Hindu Dengan Parisada}

Untuk membangun keyakinan sumber daya masyarakat Hindu di Nusa Tenggara Barat atau menanamkan nilai-nilai tertentu yang melandasi atau mempengaruhi sikap dan perilaku umat Hindu yang konsisten, maka suatu faktor-faktor yang dapat mempengaruhi budaya kerja Bimas Hindu dengan Parisada dalam pembinaan umat sebagai berikut. 1) Bidang Bimas Hindu dengan Parisada berperilaku pemimpinumat, sebagaipemimpin umat agar memiliki prilaku yang baik sebagai cerminan penting bagi umat Hindu sebagai guru Wisesa. 2) Budaya organisasi, sebagai pimpinan umat dalam mengayomi umatnya agar memiliki kebiasaan saat ini, tradisi dan cara-cara yang umum dalam melakukan pekerjaan, dengn demikian budaya organisasi 
merupakan persepsi umum yang diyakini oleh para bawahan maupun umatnya. 3) Kejelasan misi Bidang Bimas Hindu dan Parisada, dengan memahami misi yang jelas dari kedua lembaga tersebut, akan diketahui secara utuh dan jelas suatu pekerjaan yang seharusnya dilaukan baik oleh bawahan maupun dalam menjalankan tugas-tuas sebagai pimpinan lembaga. 4) Motivasi, suatu budaya kerja oleh lembaga umat Hindu baik Bimas Hindu dan Parisada dalam melakukan pembinaan ke katong-kantong umat Hindu membutuhkan dorongan untuk turut dalam memecahkan segala permasalah yang dihadapi oleh umat Hindu dimanapun mereka berada.

Kesemua faktor-faktor inilah sebagai perilaku pimpinan lembaga yang mempengaruhi pelaksanaan budaya kerja dalam suatu lembaga atau organisasi, keteladanan untuk dijadikan contoh dan panutan oleh semua pihak, juga kebijakan dalam menentukan arah, tujuan suatu visi dan misi suatu lembaga akan dijadikan landasan dalam melaksanakan budaya kerja. Dengan faktor budaya kerja, sehingga adanya suatu keyakinan yang kuat dalam merefleksikan nilai-nilai tertentu, seperti; membiasakan kerja yang berkualutas sesuai standar, efektif, produkif, dan efisien adalah merupakan awal budaya kerja yangbaik.

\section{Tujuan dan Manfaat Budaya Kerja Bidang Bimas Hindu dan Parisada}

Budaya secara umum memiliki tujuan untuk mengubah sikap dan juga perilaku SDM yang tersedia dan dapat meningkatkan produktivitas kerja untuk menghadapi berbagai tantangan hidup di masa yang akan datang.

Mengaktualisasikan budaya kerja Bidang Bimas Hindu dengan Parisada seperti; integritas, keteladanan, profesional, inovasi, dan tanggung jawab merupakan ukuran sistem nilai dalam kerja, yang pertama kali harus diupayakan adalah penanaman dalam sikap mental yang meliputi pemahaman dan pelaksanaan dalam sikap serta pelaksanaan pembinaan terhadap umat Hindu yang ada di daerah-daerah.

Di dalam budaya kerja terdapat etos kerja, budaya kerja dan etos kerja adalah dua halyang sangat penting dan saling keterkaitan, karena pekerjaan tanpa etos kerja, pekerjaan tidak akan selesai, sedangkan etos kerja Bidang Bimas Hindu dengan Parisada sangat dibutuhkan bagi umat Hindu sebagai landasan budaya kerja kedua pimpinan lembaga untuk memberikan dorongan, motivasi kepada umat Hindu di saat menjalankan swadharmanya sebagai pembina umat. Etos kerja merupakan pandangan hidup yang khas dari suatu golongan sosial. Kata Etos berasal dari bahasa Yunani yaitu "ethikos" yang berarti moral, sikap, watak , kerakter, kepribadian dan keyakinan, bahkaan dapat dikatakan etos pada dasarnya menyangkut tentang etika. Sikap bukan saja dimiliki oleh individu, tetapi ada pada setiap kelompok bahkan masyarakat. Sedangkan kerja merupakan sesuatu yang dikeluarkan oleh seseorang sebagai profesi, dan sengaja dilakukan untuk mendapatkan penghasilan. Jadi etos kerja merupakan sikap, perilaku, dan karakter yang dilakukan sebagai profesi untuk mendapatkan penghasilan.

Tujuan budaya kerja Bimas Hindu dengan Parisada adalah untuk merubah sikap dan perilaku SDM umat Hindu yang tersedia agar dapat meningkatkan produktivitas kerja untuk menghadapi berbagai tantangan dimasa yang akan datang seperti; membangun rasa kebersamaan beragama, menciptakan suasana harmonis antar, intern umat beragama, adanya rasa gotong royong, adanya sikap keterbukaan antar umat beragama, dan lain-lainnya.

Manfaatnnya budaya kerja Bidang Bimas Hindu dengan Parisada adalah untuk meningkatkan jiwa gotong royong diantara umat beragama, miningkatkan jiwa kekeluargaan diantara umat beragama dan sesama manuisa, tanggap terhadap perkembangan dunia luar danlain-lainnya. Budaya kerja Bimas Hindu dengan Parisada 
merupakan reliasasi nilai yang perlu dimiliki setiap individu untuk senantiasa bekerja, berhasil dan terpuji oleh umat Hindu maupuan umat lain dimanapun mereka berada. Juga manfaat budaya kerja adalah untuk meningkatkan kualitas Sumber Daya umat Hindu itu sendiri, meningkatkan kualitas hasil pembinaan Bidang Bimas Hindu dengan Parisada, yang menjadi harapan masyarakat Hindu kedepan.

\section{Fungsi Budaya Kerja Bidang Bimas Hindu dengan Parisada.}

Fungsi budaya kerja Bimas Hindu dangan Parisada secara umum untuk membangun keyakinan umat Hindu atau menanamkan nilai-nilai tertentu sumber daya manusia, sikap dan perilaku yang konsisten serta komitmen yang dalam membiasakan suatu cara kerja di lingkungan kerja baik kerja Bidang Bimas Hindu maupun kerja Parisada. Secara praktek di lapangan dalam menangani umat antara lain sebagai berikut:

a. Identitas organisasi (simbol dan harapan), sehingga anggota organisasi merasa bangga terhadap organisasinya dan pihak eksternal menaruh respek.

b. Kestabilan organisasi sehingga secara internal seluruh karyawan/pegawai merasa tenang dan yakin, demikian pula pihak masyarakat yang berkepentingan.

c. Sebagai alat pendorong organisasi, sehingga mampu menjadi dasar dan pendorong untuk mencapai tujuan organisasi.

d. Komitmen organisasi sehingga mampu sebagai katalisator dalam membentuk komitmen untuk pelaksanaan berbagai ide atau suatu rencana strategis.

Dengan adanya suatu keyakinan yang kuat dalam merefleksikan nilai-nilai tertentu, misalkan membiasakan kerja yang berkualitas sesuai standar, atau sesuai ekpektasi pelanggan (kelompok masyarakat), organisasi, efektif atau produktif dan efisien adalah merupakan awal budaya kerja yang baik.

\section{b. Proses Pembinaan yang dilaksanakan Bimas Hindu dengan Parisada di Provinsi Nusa Tenggara Barat.}

Proses pembinaan yang dilaksanakan Bimas Hindu dengan Parisada dalam pembinaan umat di Provinsi NTB. dilakukan dengan konsep ajaran agama Hindu dengan menanamkan budaya kerja berlandaskan ajaran agama. Adapun tujuannya adalah untuk menanamkan pedidikan karakter sejak dini terhadap anak di bawah umur dan meningkatkan sradha dan bhakti para generasi muda Hindu. Selanjutnya penyelenggaraan pembinaan umat dilaksanakan sebagai bagian dari pendidikan yang berbasis masyarakat yang diselenggarakan oleh lembaga sosial dan tradisional keagamaan Hindu dalam hal ini adalah Bimas Hindu dengan Parisada. Pada sisi lain Parisada merupakan lembaga sosial keagamaan dan lembaga pendidikan keagamaan walaupun secara nyata telah memberikan kontribusi yang amat besar dalam pembinaan umat Hindu yang ada di Provinsi NTB. Namun sebagian besar lembaga-lembaga diharapkan mampu memerankan fungsi sebagai perubahan sosial dalam masyarakat dan disesuaikan dengan tujuan pembinaan yang dilakukan oleh Parisada dengan Bimas Hindu. Demikian pula proses pembinaanya menggunakan berbagai metode dengan tujuan agar para pembina dapat menyampaikan materi dengan mudah kepada umat Hindu, sebaliknya umatya dapat memahami dengan apa yang disampaikan oleh pembina.

Secara fungsional pelaksanaan pembinaan yang dilakukan oleh Parisada dengan Bimas Hindu di Provinsi Nusa Tenggara Barat menjadi tanggung jawab lembaga. Namun, secara struktural pelaksanaan pembinaan umat Hindu di NTB menjadi tanggung jawab dari Kementerian Agama Provinsi Nusa Tenggara Barat khusunya Bidang Bimas Hindu baik melalui guru Agama maupun Parisada. Untuk mengemban fungsi tersebut, dibutuhkan tenaga yang diorbitkan oleh 
Bimas Hindu melaui Dirjen Bimas Hindu berupa penyuluh yang memiliki kemampuan dalam menjalankan program-program yang telah ditentukan. Dalam melaksanakan tugas dan fungsinya, perilaku penyuluh agama Hindu di lingkungan Kementerian Agama Provinsi Nusa Tenggara Barat tentunya juga dipengaruhi oleh iklim kerja yang telah terbentuk di Kementerian Agama Hindu tersebut. Untuk melakukan proses pembinaan Parisada dengan Bimas Hindu telah memiliki tugas dan fungsi antara lain:

\section{Tugas Pokok dan Fungsi Parisada a. Tugas Pokok Parisada}

Upaya melaksanakan dan mengembangkan kegiatan pembinaan umat Hindu dan pembangunan dilakukan melaui bahasa agama. Tugas pokok Parisada yang termuat dalam anggaran Dasar Pasal 10 adalah Pertama melayani umat Hindu dalam meningkatkan pemahaman, penghayan, dan pengalaman ajaran suci Weda. Kedua, meningkatkan pengabdian dan peran umat Hindu dalam kehidupan bermasyarakat, berbangsa dan bernegara. Ketiga, memelihara dan mengembangkan kehidupan yang mendorong terwujudnya sikap dan perilaku yang bertanggung jawab, peduli, rukun, dan harmonis di lingkungan intern, antar umat beragama, dan dengan pemerintah. $\mathrm{Ke}$ empat, memelihara dan mengemmbangkan kerjasama dengan setiap organisasi, badan lembaga, dan institusi yang bergerak dalam bidang keagamaan, kemasyarakatan, dan kenegaraan yang berlingkup nasional dan internasioanal. Kelima, melakukan redefinis, reinterprestasi, dan reaktualisasi pemahaman ajaran suci Weda.

Selain tugas pokok diatas dapat merumuskan serta melaksanakan kebijakan dan standardisasi di bidang bimbingan masyarakat Hindu. Hal lainya adalah melaksanakan pelayanan, bimbingan pembinaan dan pengelolaan sistem informasi di bidang bimbingan masyarakat Hindu berdasarkan kebijakan teknis yang telah ditetapkan oleh Kepala Kantor Wilayah Kementerian Agama.

\section{b. Fungsi Parisada}

Berdasarkan tugas pokok yang telah dimuat pada pasal 10 anggaran dasar, maka dalam pelaksanaan tugas tersebut melekat fungsi Parisada yang dimuat pada Pasal 9 Anggaran Dasar sebagai berikut: Pertama, menetapkan Bhisama, Kedua, mengambil keputusan di bidang keagamaan dalam hal ada perbedaan pemahaman ajaran dan atau dalam hal terdapat keragu-raguan mengani masalah tersebut. Ketiga, memasyarakatkan ajaran Weda, Bhisama, dan keputusan-keputusan Parisada. Keempat, menjadi inspirator, inisiator, dinamisator, regulator, mediator, dan stabilisator yangberkaitan dengan eksistensi umat. Pada fungsi yang lain dapat dikalsifikasikan sebagi berikut;

1). Fungsi Informatif dan Edukatif

Fungsi informatif dan edukatif adalah dimana Parisada dengan Bidang Bimas Hindu memosisikan dirinya sebagai orang yang berkewajiban menyampaikan pesan-pesan ajaran agama dan membina masyarakat dengan sebaik-baiknya sesuai dengan tuntunan kitab suci Veda dan para Rsi.

2). Fungsi Konsultatif

Fungsi konsultatif, yaitu dimana Bimas Hindu dengan Parisada menyediakan dirinya untuk turut memikirkan dan memecahkan permasalah yang dihadapi masyarakat, baik persoalan pribadi, keluarga, maupun masyarakat secara umum.

3). Fungsi Advokatif

Fungsi advokatif, yaitu Bimas Hindu dengan Parisada memiliki tanggung jawab moral dan sosial untuk melakukan kegiatan pembelaan terhadap masyarakat dari segala bentuk kegiatan pemikiran yang akan merusak kaidah dan tatanan kehidupan beragama, baik terjadi dalam 
keluarga maupun dalam masyarakat umum. Hal itu penting mengingat fungsi Parisada dan Bimas Hindu adalah mengembangkan kegiatan bimbingan dan penyuluhan agama serta pembangunan melalui bahasa agama.

\section{Metode Pembinaan Umat oleh Bimas Hindu dengan Parisada}

Pada prinsipnya dalam penerapan metode pembinaan Umat Hindu yang dilakukan Bimas Hindu dengan Parisada pada umumnya menggunakan beberapa metode. Metodemetode tersebut adalah sebagai berikut.

\section{a. Metode Ceramah}

Metode ceramah sangat efektif untuk jumlah yang relatif banyak dan tidak memerlukan umpan balik dari peserta yang dibina secara langsung atau interaktif Metode ini hampir mirip dengan dharma wecana, hanya dharma wecana umum dilakukan pada hari raya suci dan bertempat di pura atau di balai masyarakat. Keuntungan yang dapat diperoleh dengan metode ini ialah sifatnya mudah, memungkinkan untuk eksplorasi materi seluas-luasnya sehingga sasarannya dimengerti. Namun, juga terdapat beberapa syarat untuk memaksimalkan metode ini, antara lain diperlukan kecakapan pembina dalam mengolah meteri dan menyajikannya sehingga sasaran binaannya tidak mengalami kejenuhan. Karena jumlah sasaran atau peserta banyak maka diperlukan alat bantu berupa LCD untuk menyampaikan materi binaan sehingga kelemahannnya adalah sedikit memberikan peluang bagi peserta untuk aktif bertanya mengenai hal-hal yang mungkin masih belum jelas baginya.

Metode ceramah merupakan suatu metode dengan menggunakan seperangkat pengetahuan dan olah pikir dalam mengaktualisasikan konsep-konsep yang dapat dikolaborasikan serta dipadukan kemudian disampaikan kepada peserta didik. Hal ini akan memberikan rangsangan atau stimulus kepada peserta didik untuk mengkaji serta menganailisis sehingga menghasilkan suatu pemikiran yang dapat digunakan dalam bertindak.

\section{b. Metode Dialog}

Metode dialog ini pada umumnya dilaksanakan oleh Parisada dan Bimas Hindu dalam memberikan pembinaan terhadap masyarakat. Dalam hal ini Parisada memerankan dirinya sebagai konselor atau konsultan bagi daerah binaannya. Dengan metode dialog diharapkan tumbuh kedekatan personal sehingga tidak ada batas-batas sosial atau pengotak-ngotakan yang menjadi sekat dalam berinteraksi antara pembina dengan masyarakat yang dibina atau objek binaannya. Dengan keterbukaan tersebut, pembina dapat menerapkan pendekatan empati, sehingga segala permasalahan dapat dijelaskan secara logis dan mudah menentukan alternatif penyelesaiannya. Di pihak lain pembina yang melibatkan banyak peserta, maka selayaknya dilakukan secara terencana, terprogram, dan terintegrasi dengan melibatkan aspekaspek lainnya sehingga metode dialog dapat tercapai sesuai dengan sasaran. Metode dialog berisikan pertukaran pendapat yang dijalankan dengan pertanyaan-pertanyaan problematis, pemunculan ide-ide, pengujian ide-ide ataupun pendapat yang dilakukan oleh beberapa peserta yang dibina. Adapun manfaat metode ini adalah (1) para pengelola atau pembina memperoleh kesempatan untuk berpikir, (2) pengelola dan pembina mendapat kesempatan untuk mengeluarkan pendapat, sikap, dan aspirasinya secara bebas, (3) pembina belajar bersikap toleransi terhadap masyarakat, (4) dapat mengembangkan sikap demokratik, dan (5) dapat menghargai pendapat orang lain.

Adapun kelemahan metode ini adalah (1) terlampau menyerap waktu terlalu lama, (2) pada umumnya pengelola pasraman tidak berlatih untuk melakukan dialog, dan (3) kadang-kadang penyuluh tidak memahami cara-cara melakukan dialog (Segala, 2012: 
208-209 ). Dalam melaksanakan aktivitas pembinaan suatu dialog merupakan parameter untuk mencapai hasil pembinaan secara efektif. Di katakan demikian mengingat dialog merupakan suatu metode yang akurat yang dapat mengubah perilaku berpikir ke arah yang lebih maju dan berkembang. Untuk itu, diperlukan suatu metode dialog yang baik dan struktur dalam melaksanakan suatu pembinaan umatHindu yang ada di Provinsi NTB. Hal tersebut dapat divisualisasikan dalam gambar di bawah ini

\section{c. Metode Wisata Religi}

Metode wisata religi dapat disebut dharma yatra yaitu melakukan perjalanan suci untuk mengunjungi tempat-tempat suci dan bersejarah. Metode ini sebetulnya dapat dilakukan di tempat-tempat yang dianggap lebih baik bagi kehidupan keberagamaan sehingga menjadi komparansi yang memadai untuk meningkatkan gairah keberagamaan pada masyarakat hindu yang ada di daerahdaerah pelosok yang adadi Provinsi NTB.

Penyuluh memberikan pembinaan dan pengarahansebelumberangkatmenuju tempattempat suci yang ada di Lombok dengan maksud peserta bisa mendeskripsikan apa yang ditemukan dan dialami dalam melakukan wisata religi. Manfaat yang diperoleh dari metode ini ialah para peserta atau sasaran binaan penyuluh diajak untuk berinteraksi dengan kelompok masyarakat lain.selain itu, juga menilai dan menghargai artifak-artifak peninggalan masa lalu yang berpengaruh terhadap kehidupan keberagamaan masa kini. Dengan memperoleh kesan langsung diharapkan menjadi motivasi untuk meningkatkan kualitas keberagamaannya. Hal-hal yang dapat dipetik dalam metode ini ialah meningkatkan wawasan sasaran binaan atau masyarakat mengenai keragaman budaya dalam keberagamaan.

\section{d. Metode Diskusi}

Metode diskusi mirip dengan tanya jawab pada aspek keterlibatan sasaran binaan. Metode ini dikatakan efektif bilamana target sasaran binaan memiliki potensi pengetahuan memadai. Hal ini dilakukan secara bersamasama oleh Bimas Hindu dengan Parisada dan anggota masyarakat diskusi untuk memecahkan suatu pokok permasalahan atau pokok kajian. Pembinaan dengan metode diskusi sangat cocok digunakan pada kelompok masyarakat intelek dan terpelajar dengan jumlah terbatas dan waktu khusus. Penyampaian metode diskusi mengharuskan penyuluh dalam pemilihan topik agar betulbetul tepat sasaran. Selanjutnya dalam memberikan jawaban dapat memuaskan penanya ataupun kelompk diskusi.

Metode diskusi adalah percakapan ilmiah yang berisikan pertukaran pendapat yang dijalin dengan pertanyaan-pertanyaan atau pendapat-pendapat oleh beberapa orang dan kelompok yang diarahkan untuk memperoleh pemecahan permasalaham untuk mencari kebenaran. Dalam diskusi selalu ada suatu pokok yang dibicarakan. Topik yang dibicarakan dalam diskusi ini adalah keberadaan umat Hindu dan lembaga pendidikan nonformal agar selalu dikelola dengan profesional.

\section{KESIMPULAN}

Budaya kerja yang terbentuk secara positif oleh kedua lembaga baik dari Bidang Bimas Hindu maupun Parisada, akan bermanfaat karena setiap umat Hindu yang ada di daerahdaerah dalam suatu organisasi membutuhkan ruang lingkup yang positif dalam membangun masyarakat demi kemajuan umat Hindu di Nusa Tenggara Barat. Budaya kerja Bidang Bimas Hindu dengan Parisada berwujud baik akan berdampak terhadap umat Hindu yang merupakan masyarakat binaannya.

Untuk memperbaiki budaya kerja membutuhkan waktu untuk merubahnya, maka dari itu perlu adanya pembenahanpembenahan yang dimulai dari sikap dan tingkah laku sebagai pemimpin pada lembaga 
umat Hindu. Demikian juga masing-masing pimpinan lembaga umat, baik Bidang Bimas Hindu maupun Parisada telah memilki tugas dan fungsi masing-masing. Tugas dan fungsi Bidang Bimas Hindu dengan Parisada dalam melakukan pembinaan, yaitu 1) melaksanakan pelayanan dan bimbingan masyarakat Hindu, 2) melaksanakan fungsi penjabaran dan pelaksanaan kebijakan teknis di bidang bimbingan masyarakat Hindu, 3) akan terjaganya keutuhan masyarakat Hindu dengan mengakomodasikan kearifan budaya lokal, dan 4) terwujudnya masyarakat Hindu yang berkualitas dan memiliki srada dan bhakti yang mampu diaktualisasikan secara modern

Proses pembinaan yang dilaksanakan Bimas Hindu dengan Parisada dalam pembinaan umat di Provinsi NTB. dilakukan dengan konsep ajaran agama Hindu dengan menanamkan budaya kerja berlandaskan ajaran agama. Adapun tujuannya adalah untuk menanamkan pedidikan karakter sejak dini terhadap para generasi dan meningkatkan sradha dan bhakti pada masyarakat. Selanjutnya penyelenggaraan pembinaan umat dilaksanakan sebagai bagian dari pendidikan yang berbasis masyarakat yang diselenggarakan oleh lembaga sosial dan tradisional keagamaan Hindu dalam hal ini adalah Bimas Hindu dengan Parisada.

Pada sisi lain Parisada merupakan lembaga sosial keagamaan dan lembaga pendidikan keagamaan walaupun secara nyata telah memberikan kontribusi yang amat besar dalam pembinaan umat Hindu yang ada di Provinsi NTB. Namun sebagian besar lembaga-lembaga diharapkan mampu memerankan fungsi sebagai perubahan sosial dalam masyarakat dan disesuaikan dengan tujuan pembinaan yang dilakukan oleh Parisada dengan Bimas Hindu. Demikian pula proses pembinaanya menggunakan berbagai metode dengan tujuan agar para pembina dapat menyampaikan materi dengan mudah kepada umat Hindu, sebaliknya umatya dapat memahami dengan apa yang disampaikan oleh pembina.

\section{DAFTAR PUSTAKA}

Achmad Darodjat, 2015. Pentingnya Budaya kerja, Bandung: PT Refika Aditama.

Ahmad Batinggi, 1999. Manajemen Pelayanan Umum, Jakarta: Unuversitas Terbuka.

Badudu-Zin. 2001. Pembinaan Karier Pegawai. Jakarta: Raja Gerafindo Persada

Chaplin, James P, 1989. Kamus Lengkap Psikologi, Terj. Kartini Kartono, Jakarta: Rajawali.

Gary Yulk, 2007. Kepemimpinan dalan Organisasi, Jakarta: Ineks.

Hasibuan, SP, 2000. Manajemen Sumber Daya Manusia, Jakarta: PT. Bumi Aksara.

Inspektorat Jenderal Departemen Agama, 2008. Modul Pengawasan dengan Pendekatan Agama, Jakarta: Inspektorat Jenderal Departemen Agama.

Keputusan Menteri Pendayagunaan Aparatur Negara RI Nomor: 25/KEP/ M.PAN/ 04/2002 Tentang Pedoman Pengembangan Budaya Kerja Aparatur Negar, Jakarta.

Sudiarta. 2009. Tesis. Budaya Birokrasi dalam Kebijakan Pembangunan Pariwisata. Denpasar: UNHI.

Tafsir, Ahmad, 1996. Pendidikan Agama Dalam Keluarga. Bandung: Remaja Rosdakarya. 